\title{
Spiroplasma species as a rare cause of congenital cataract and uveitis: a case series
}

\author{
Navid Farassat ${ }^{1 *}$, Michael Reich ${ }^{1}$, Annerose Serr ${ }^{2}$, Sebastian Küchlin ${ }^{1}$, Marwa Erwemi ${ }^{3}$, Claudia Auw-Hädrich $^{1}$, \\ Hermann Krastel $^{3}$ and Wolf Alexander Lagrèze ${ }^{1}$
}

\begin{abstract}
Background: To date, only four cases of ocular spiroplasma infection have been reported in the entire ophthalmic literature. We add two more cases to raise awareness of this sight-threatening congenital disease that manifests as cataract with ocular inflammation.
\end{abstract}

Case presentation: Both infants were referred for cataracts associated with ocular inflammation. Case 1, a 3-weekold neonate presented with unilateral cataract, ocular inflammation and elevated intraocular pressure. Case 2 was a 3-month-old infant with bilateral cataract and panuveitis. Lensectomies with or without vitrectomy and subsequent analyses of the specimens were performed. Transmission electron microscopy and multiplex polymerase chain reaction or $16 \mathrm{~s}$ rRNA gene polymerase chain reaction revealed spiroplasma species.

Conclusions: Spiroplasma as a very rare cause for congenital cataract might be underdiagnosed. We recommend performing polymerase chain reaction to probe for spiroplasma species in congenital cataracts with an inflammatory component.

Keywords: Spiroplasma ixodetis, Congenital cataract, Uveitis

\section{Background}

Congenital cataract is a leading cause of childhood blindness [1]. While most cases occur on a genetic or maldevelopmental basis, the exact etiology may remain elusive in the context of ocular inflammation. Infectious causes of congenital cataracts are often summarized with the acronym TORCH. Common pathogens of the TORCH group are toxoplasmosis, rubella, $\mathrm{CMV}$ and herpes simplex. The "O" represents other rare pathogens. We here report two cases of congenital cataract and uveitis due to spiroplasma species to raise awareness for this rare sightthreatening condition. One of these cases represents the first in the literature to show not only inflammation of

*Correspondence: navid.farassat@uniklinik-freiburg.de

${ }^{1}$ Eye Center, Medical Center, Faculty of Medicine, Albert-Ludwig University Freiburg, Killianstraße 5, 79106 Freiburg, Germany

Full list of author information is available at the end of the article the anterior segment but also of the posterior segment of the eye.

\section{Case presentation}

\section{Case 1}

A slightly premature born (35w 5d), 3-week-old, otherwise healthy infant was referred for a white fleck OD after inconspicuous pregnancy. Family history for congenital cataracts was negative. Examination revealed anterior uveitis with a very shallow anterior chamber, circular anterior synechiae in the chamber angle, a delicate fibrine pupillary membrane with posterior synechiae and a diffuse whitish opacification of the entire lens. The iris was hyperemic with straight and prominent vessels extending slightly onto the lens (Fig. 1A, B). Initial intraocular pressure (IOP) measured $26 \mathrm{mmHg}$ OD. Corneal diameter OD was increased to $11.5 \mathrm{~mm}(10 \mathrm{~mm}$ OS) and axial length was $19.2 \mathrm{~mm}$ OD (17.1 mm OS). After a 5-week course of a topical and systemic anti-inflammatory, original author(s) and the source, provide a link to the Creative Commons licence, and indicate if changes were made. The images or other third party material in this article are included in the article's Creative Commons licence, unless indicated otherwise in a credit line to the material. If material is not included in the article's Creative Commons licence and your intended use is not permitted by statutory regulation or exceeds the permitted use, you will need to obtain permission directly from the copyright holder. To view a copy of this licence, visit http://creativecommons.org/licenses/by/4.0/. The Creative Commons Public Domain Dedication waiver (http://creativeco mmons.org/publicdomain/zero/1.0/) applies to the data made available in this article, unless otherwise stated in a credit line to the data. 


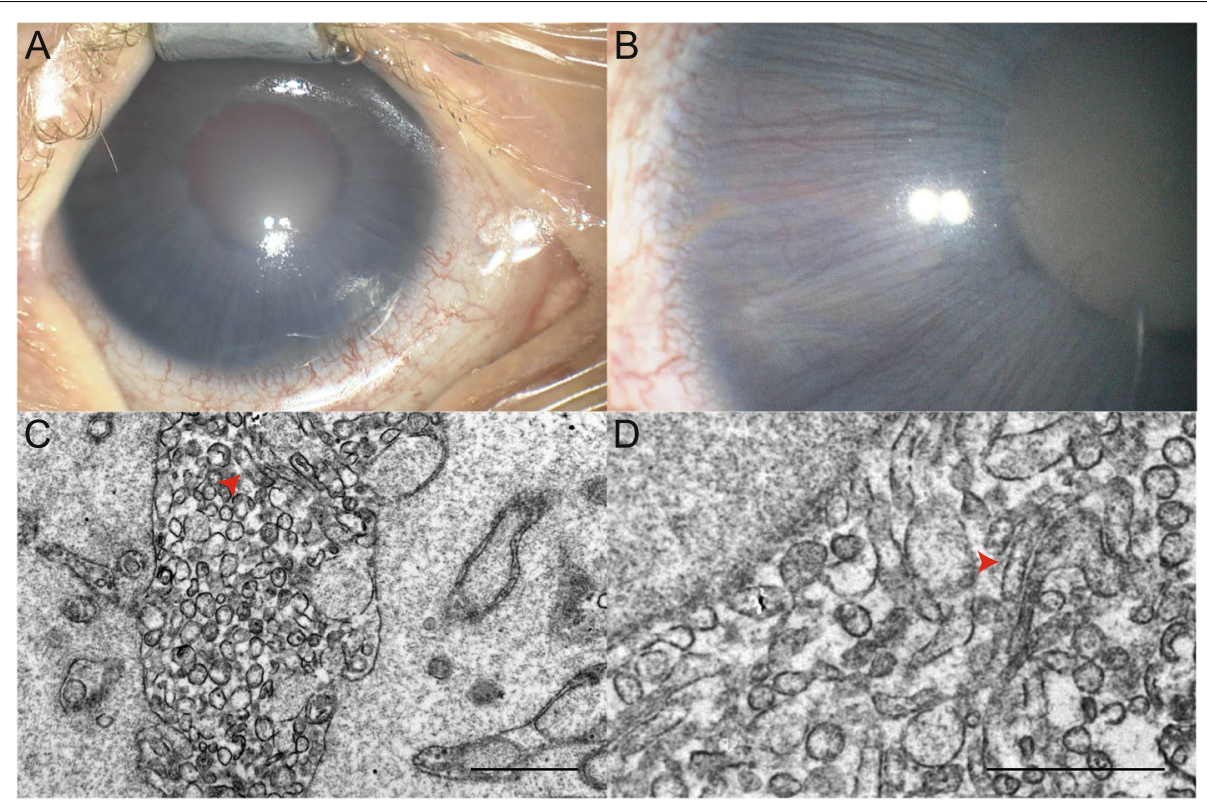

Fig. 1 Case 1. A, B Anterior segment OD of patient 1 showing a diffusely opacified lens and a hyperemic iris with straight and prominent vessels extending onto the lens. C, D Transmission electron microscopy images of crystalline lens material revealing multiple intracellular, rod-shaped, filamentous and round-shaped microorganisms (red arrowheads), scale bar $=1 \mu \mathrm{m}$

antibiotic and IOP-lowering therapeutic regimen, synechiolysis and lensectomy were performed. The vitreous was not infiltrated and the retina appeared normal. Dexamethasone, vancomycin and ceftazidime (each $0.1 \mathrm{ml}$ of vancomycin $10 \mathrm{mg} / \mathrm{ml}$, ceftazidime $20 \mathrm{mg} / \mathrm{ml}$, dexamethasone $4.44 \mathrm{mg} / \mathrm{ml}$ ) were injected intravitreally. Postoperatively, the patient received tapering topical steroids. Polymerase chain reaction (PCR; comprising panfungal PCR, Toxoplasma gondii qPCR, eubacterial PCR, Herpes simplex 1/2 PCR, Chlamydia trachomatis qPCR, Myoplasma genitalium qPCR, Mycoplasma hominis qPCR, Ureaplasma urealyticum/parvum qPCR and Mycoplasma multiplex n-PCR) of the lensectomy probes was performed. Mycoplasma multiplex n-PCR revealed spiroplasma species. 16s rRNA gene PCR and sequencing identified spiroplasma ixodetis as the subspecies. Other infectious causes of congenital cataracts were ruled out either through PCR of lens specimens (Herpes simplex, Toxoplasmosis), serologically (CMV) or clinically (Rubella). Transmission electron microscopy (TEM) of lens fragments collected without centrifugation visualized intracytoplasmic irregular, filamentous and round microorganisms matching previous reports of spiroplasma (Fig. 1C, D). Postoperatively, a contact lens was fitted and occlusion therapy was initiated.

\section{Case 2}

At the age of 3 months, a full-term male infant was referred for bilateral cataracts OU. Family history for congenital cataracts was negative. We found diffuse white cataracts obscuring the fundus OU. Concomitant inflammation of the anterior segments with corneal precipitates, posterior synechiae and small pupillary granulomata OU was detected (Fig. 2A). Ultrasonography showed infiltration of the vitreous and attached retinas OU. IOPs were normal. Lensectomy and synechiolysis was performed sequentially OU. Intraoperatively, the vitreous showed mild cellular infiltration and snowballs. The peripheral retina exhibited few whitish, partially necrotic lesions (Fig. 2B). Postoperatively, systemic therapy was initiated with intravenous methylprednisolone $30 \mathrm{mg} /$ $\mathrm{kg} / \mathrm{d}$ for 3 days and oral erythromycin for 21 days. Topical steroids were tapered within 3 weeks. PCR (comprising panfungal PCR, Toxoplasma gondii qPCR, Bartonella henselae n-PCR, Mycobacterium n-PCR, $M$. tuberculosis complex n-PCR, eubacterial PCR, and Mycoplasma multiplex n-PCR) of vitreous probes revealed spiroplasma species. Subspecies identification through $16 \mathrm{~s}$ rRNA gene PCR was not performed. Other infectious causes of congenital cataracts were ruled out through PCR of vitreous probes (Toxoplasmosis, CMV, Rubella). TEM of a vitrectomy centrifugate showed rod-shaped structures matching spiroplasma. However, this mode of specimen preparation did not allow for high quality imaging and therefore these images are not presented herein. Five years after lensectomies, visual acuity was 20/200 OD and 20/100 OS with aphakia spectacles for optical correction. Aphakic glaucoma did not occur. 


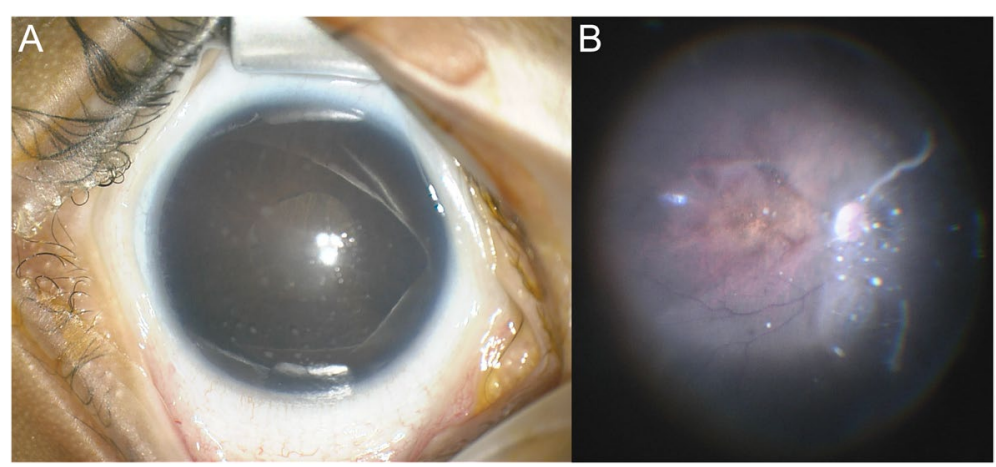

Fig. 2 Case 2. A Anterior segment OD of patient 2 showing a diffuse cataract and corneal precipitates. B Intraoperative funduscopic image OD revealing vitreous infiltration

\section{Discussion and conclusions}

We present two cases of congenital cataract and concomitant intraocular inflammation due to infection with spiroplasma species. Spiroplasma is a small helical genus of mollicutes, a type of intracellularly growing bacteria without a cell wall. It colonizes plants, arachnids and insects and has been shown to exhibit a mostly symbiotic, rarely pathogenic interaction with its hosts [2]. Little is known about the transmission between animal and human hosts. Nevertheless, spiroplasma ixodetis has been related to four cases of congenital cataract with anterior uveitis, suggesting intrauterine transmission [3, 4]. Two patients each were affected either uni- or bilaterally. Lorenz et al. were the first to report such a case in 2002 [3]. In contrast to these reports, patient 2 in this study showed inflammation not only of the anterior but also of the posterior segment. This is in accordance with experimental studies: Spiroplasma mirum, isolated from rabbit ticks in Georgia, USA, also known as the suckling mouse cataract agent (SMCA), caused panophthalmitis and microphthalmia in newborn mice, rats, hamsters and rabbits when inoculated intracerebrally. Of note, adult animals were resistant [5-7]. Likewise, there are no reports of ocular spiroplasma infections in adult humans. However, three reported cases of systemic infections in immunocompromised adult patients indicate that spiroplasma species do not exclusively affect infants $[8,9,10]$.

Spiroplasma as a very rare infectious cause of congenital cataract might be underdiagnosed, as neither specific serology, PCR nor TEM are part of routine diagnostics. We therefore recommend performing PCR to probe for this entity in congenital cataracts with an inflammatory component.

\section{Abbreviations}

IOP: Intraocular pressure; PCR: Polymerase chain reaction; SMCA: Suckling mouse cataract agent; TEM: Transmission electron microscopy.

\section{Supplementary Information}

The online version contains supplementary material available at https://doi. org/10.1186/s12886-021-02201-0.

\section{Additional file 1.}

\section{Acknowledgements}

We thank Dr. Alexandra Müller from the Institute of Neuropathology, University Hospital Freiburg, for providing the transmission electron microscopy images and for her kind and excellent technical support.

\section{Authors' contributions}

Conception and design: NF and WL; Data collection: NF, WL, ME, HK; Analysis and interpretation: all authors; Writing the article: NF and WL; Critical revision: all authors; Final approval: all authors. All authors have read and approved the manuscript.

\section{Funding}

Open Access funding enabled and organized by Projekt DEAL. No funding or financial support was received for this study.

\section{Availability of data and materials}

The datasets used and/or analysed during the current study are available from the corresponding author on reasonable request.

\section{Declarations}

Ethics approval and consent to participate

Ethics Committee approval was not required. The study adhered to the tenets of the Declaration of Helsinki. The authors declare that they adhered to the CARE guidelines/methodology.

\section{Consent for publication}

Parents of both patients provided written informed consent for the publication of the cases and any accompanying images.

\section{Competing interests}

The authors declare that they have no competing interests.

\section{Author details}

${ }^{1}$ Eye Center, Medical Center, Faculty of Medicine, Albert-Ludwig University Freiburg, Killianstraße 5, 79106 Freiburg, Germany. ${ }^{2}$ Institute for Microbiology and Hygiene, Faculty of Medicine, University of Freiburg, Freiburg, Germany.

${ }^{3}$ Department of Ophthalmology, Medical Faculty Mannheim, Ruprecht-KarlsUniversity Heidelberg, Heidelberg, Germany. 
Received: 28 July 2021 Accepted: 5 December 2021

Published online: 15 December 2021

\section{References}

1. Lambert SR. Treatment of congenital cataract. Br J Ophthalmol. 2004 Jul;88(7):854-5.

2. Cisak E, Wójcik-Fatla A, Zając V, Sawczyn A, Sroka J, Dutkiewicz J. Spiroplasma - an emerging arthropod-borne pathogen? Ann Agric Environ Med. 2015;22(4):589-93.

3. Lorenz B, Schroeder J, Reischl U. First evidence of an endogenous Spiroplasma sp. infection in humans manifesting as unilateral cataract associated with anterior uveitis in a premature baby. Graefes Arch Clin Exp Ophthalmol. 2002;240(5):348-53.

4. Matet A, Le Flèche-Matéos A, Doz F, Dureau P, Cassoux N. Ocular spiroplasma ixodetis in newborns, France. Emerg Infect Dis. 2020;26(2):340-4.

5. Clark HF. Rat cataract induced by suckling mouse cataract agent. Am J Ophthalmol. 1969;68(2):304-8.

6. Kirchhoff H, Heitmann J, Trautwein G. Pathogenicity of Spiroplasma sp. strain SMCA in Syrian hamsters: clinical, microbiological, and histological aspects. Infect Immun. 1981:33(1):292-6.

7. Kirchhoff H, Heitmann J, Trautwein G. Pathogenicity of Spiroplasma sp. strain SMCA in rabbits: clinical, microbiological, and histological aspects. Infect Immun. 1981;33(1):292-6.

8. Aquilino A, Masiá M, López P, Galiana AJ, Tovar J, Andrés M, et al. First human systemic infection caused by spiroplasma. J Clin Microbiol. 2015;53(2):719-21.

9. Etienne $\mathrm{N}$, Bret L, Le Brun C, Lecuyer H, Moraly J, Lanternier F, Hermine O, Ferroni A, Lecuit M, Pereyre S, Beven L. Emerg Infect Dis. 2018:24(12):2382-6. https://doi.org/10.3201/eid2412.180567.

10. Mueller NJ, Tini GM, Weber A, Gaspert A, Husmann L, Bloemberg G, Boehler A, Benden C. Am J Transplant. 2015;15(9):2511-6. https://doi.org/ 10.1111/ajt.13254

\section{Publisher's Note}

Springer Nature remains neutral with regard to jurisdictional claims in published maps and institutional affiliations.

Ready to submit your research? Choose BMC and benefit from:

- fast, convenient online submission

- thorough peer review by experienced researchers in your field

- rapid publication on acceptance

- support for research data, including large and complex data types

- gold Open Access which fosters wider collaboration and increased citations

- maximum visibility for your research: over 100M website views per year

At BMC, research is always in progress.

Learn more biomedcentral.com/submissions 